\title{
IAMJ
}

INTERNATIONAL

AYURVEDIC

MEDICAL JOURNAL

\section{CRITICAL EVALUATION OF THE ACTION OF VARIVIDARYADI KASHAYA IN LOWER URINARY TRACT INFECTIONS}

\section{$\underline{\text { Anshu } S^{1}}$, Miharjan $K^{2}, \underline{\text { Arjun Chand C } \mathbf{P}^{3}}$, $\underline{\text { Arun Pratap }}^{4}$}

${ }^{1}$ Final year P.G Scholar, ${ }^{2}$ Former Professor \& Head, ${ }^{3}$ Associate Professor, ${ }^{4}$ Professor and Head, Dept of Kayachikitsa, Pankajakasthuri Ayurveda Medical College and P.G Centre, Kattakada, Trivandrum, Kerala, India

Corresponding Author: dranshus1993@gmail.com

\section{https://doi.org/10.46607/iamj2209112021}

(Published Online: November 2021)

Open Access

(C) International Ayurvedic Medical Journal, India

Article Received: 17/10//2021 - Peer Reviewed: 30/10/2021 - Accepted for Publication: 31/10/2021

\section{Check for updates}

\section{ABSTRACT}

Urinary tract infection (UTI) is a common and painful human illness that is rapidly responsive to modern antibiotic therapy. UTI is caused by both Gram-negative and Gram-positive bacteria, as well as by certain fungi. The typical symptoms of lower urinary tract infections (LUTI) are dysuria, urinary frequency, and urgency, nocturia, hesitancy, suprapubic discomfort, and gross hematuria. The features of LUTI can be found under the heading Pittaja Mutrakrichra Lakshana. As Pitta and Vata are the main Doshas involved in the Samprapti of this disease, drugs having Madhura Rasa, Vata-Pitta Samana properties are the ideal choice for the treatment. In Varividaryadi Kashaya, all the drugs are having Sita Virya and most of the drugs are having Madhura Rasa, Guru-Snigdha Guna, and Madhura Vipaka. So, there is a very need to understand the scope of the usage of Varividaryadi Kashaya in the management of LUTI.

Keywords: Urinary tract infection, Pittaja Mutrakrichra, Varividaryadi Kashaya

\section{INTRODUCTION}

Urinary tract infections (UTI) are some of the most common bacterial infections, affecting 150 million people each year worldwide ${ }^{1}$. The features of UTI can be found under the heading Pittaja Mutrakrichra Lakshanas. As Pitta and Vata are the main Doshas involved in the Samprapti of the disease, drugs hav- ing Madhura Rasa, Vata-Pitta Samana properties are the ideal choice for the treatment and in Varividaryadi Kashaya, all the drugs are having Sita Virya and most of the drugs are having Madhura Rasa, GuruSnigdha Guna, and Madhura Vipaka. So, there is a very need to understand the scope of the usage of 
Varividaryadi Kashaya in the treatment of lower urinary tract infections.

\section{DISEASE REVIEW}

Urinary tract infection (UTI) is a common and painful human illness that, fortunately, is rapidly responsive to modern antibiotic therapy. UTI may be asymptomatic (subclinical infection) or symptomatic (disease). Thus, the term UTI encompasses a variety of clinical entities, including asymptomatic bacteriuria (ASB), cystitis, prostatitis, and pylelonephritis ${ }^{2}$. UTI is caused by both Gram-negative and Grampositive bacteria, as well as by certain fungi. The most common causative agent for both uncomplicated and complicated UTI is uropathogenic Escherichia coli (UPEC) and is followed in prevalence by Klebsiella pneumonia, Enterococcus faecalis, Pseudomonas aeruginosa, Staphylococcus aureus and several species of Candida. Several risk factors are associated with cystitis/lower urinary tract infection (LUTI), including female gender, a prior UTI, sexual activity, vaginal infection, diabetes, obesity and genetic susceptibility. A LUTI typically starts with periurethral contamination by an uropathogen residing in the gut, followedby colonization at the urethra and subsequent migration of the pathogen to the bladder. In the bladder, the consequences of complex host-pathogen interactions ultimately determine whether uropathogen are successful in colonization or eliminated ${ }^{1}$. The typical symptoms of cystitis are dysuria, urinary frequency, and urgency. Nocturia, hesitancy, suprapubic discomfort, and gross hematuria are also noted ${ }^{2}$. Currently, antibiotics - such as trimethoprim sulfamethoxazole, ciprofloxacin and ampicillin — are the most commonly recommended therapeutics for UTI ${ }^{1}$. However, UTIs are becoming increasingly difficult to treat owing to the widespread emergence of antibiotic resistance mechanisms and high recurrence rates.

In Ayurveda, UTI can be correlated with Mutrakrichra. The disease in which Mutra is passed with difficulty is called Mutrakrichra ${ }^{3}$. As burning micturition is the predominant symptom of LUTI which suggests the involvement of Pitta Dushti in the mani- festation of this disease; also, the symptoms such as Peeta Mutrata, Sarakta Mutra, Sadaha, Saruk, Krichra and Muhur Mutra can be seen in this condition; so, it can be correlated with Pittaja Mutrakrichra.

\section{Nidana}

Mutrakrichra Nidana has been very well explained by Acharya Charaka. But Acharya Susrutha and Acharya Vagbhata has not mentioned any special Nidana for Mutrakrichra. They have considered Asmari and Shalya as the etiological factors. The Nidana can be divided into Samanya Nidana and Vishishta Nidana. Etiological factors that cause the vitiation of Mutravaha Srotas can be taken as the Samanya Nidana. According to Acharya Charaka, Mutravaha Srotas gets vitiated because of the intake of drinks or foods, or sexual intercourse while having the urge for micturition; and suppression of the urge for micturition especially by those suffering from wasting and injury ${ }^{4}$. Vishishta Nidana Aharaja Nidana like Rooksha Ahara, Madhyasevana, Anoopa Mamsa Sevana, Matsyasevana, Adhyasana, Ajeerna Bhojana, Katu, Amla, Lavana Rasa Ati Sevana, Viharaja Nidana like Ativyayama, Nityadrutaprushta Yana, Sthreesevana, Vegadharana and Oushadhajanya Nidana like intake of Teekshna Oushada etc ${ }^{5}$.

\section{Samprapti}

Due to the Aharaja, Viharaja and Oushadhajanya Nidana Sevana, Pitta and Vata Dosha Prakopa occurs in the body. This Prakupita Pitta and Vata result in Agni Dushti and ends in the formation of Ama. From this Ama, Ama Yukta Rasa Dhatu is formed. From this, Dushita Rakta gets formed and in turn produces Mala Roopa Pitta in excess. Because of the Tikshna and Ushna Guna of the Mala Roopa Pitta, Kleda Soshana occurs. Thus formed Mutra, from the Kledamsha of Rakta will also possess similar qualities and reaches Basti through the Mutravaha Srotos. As Basti provides the seat for Apana Vayu; because of its Yogavahi Guna, Lakshanas like Peeta Mutrata, Daha, Ushna Mootrata, Krichra Mutrata etc. are exhibited. 
Table 1: Samprapti Ghataka

\begin{tabular}{|l|l|}
\hline DOSHA & Pitta, Vata \\
\hline DUSHYA & Mutra, Rasa, Rakta \\
\hline AGNI & Jatharagnimandya, Dhatvagnimandhya \\
\hline SROTAS & Mutravaha, Rasavaha \\
\hline SROTODUSHTI & Sanga \\
\hline UDBHAVA STHANA & Amashaya, Pakwashaya \\
\hline ADHISHTHANA & Basti \\
\hline SANCHARA STHANA & Mutravaha Srotas \\
\hline VYAKTHA STHANA & Mutra Marga \\
\hline ROGAMARGA & Madhyama \\
\hline SWABHAVA & Ashukari, Cirakari \\
\hline
\end{tabular}

\section{VARIVIDARYADI KASHAYA}

Varividaryadi Kashaya is mentioned in Sahasrayogam Mutrakrichra Prakaranam ${ }^{6}$.

Table 2: Botanical identity and part used of the drugs ${ }^{7-11}$

\begin{tabular}{|l|l|l|l|}
\hline DRUG & BOTANICAL NAME & FAMILY & PART USED \\
\hline Satavari & Asparagus racemosus Willd. & Liliaceae & Tuber \\
\hline Vidari & Ipomea panniculata Linn. & Papilonaceae & Tuber \\
\hline Gokshura & Tribulus terrestris Linn. & Zygophyllaceae & Fruit \\
\hline Musta & Cyperus rotundus Linn. & Cypereceae & Tuber \\
\hline Sariva & Hemidesmus indicus Linn. & Asclepiadaceae & Tuber \\
\hline
\end{tabular}

Table 3: Properties of the drugs $s^{7-10}$

\begin{tabular}{|l|l|l|l|l|}
\hline Drug & Rasa & Guna & Virya & Vipaka \\
\hline Satavari & Madhura Tikta & Guru, Snigdha & Sita & Madhura \\
\hline Vidari & Madhura & Guru, Snigdha & Sita & Madhura \\
\hline Gokshura & Madhura & Guru, Snigdha & Sita & Madhura \\
\hline Musta & Tikta, Kashaya, Katu & Laghu, Ruksha & Sita & Katu \\
\hline Sariva & Madhura & Guru, Snigdha & Sita & Madhura \\
\hline
\end{tabular}

Table 4: Karma of the drugs ${ }^{7-10}$

\begin{tabular}{|l|l|}
\hline DRUG & KARMA \\
\hline Satavari & $\begin{array}{l}\text { Vrsya, Sukraja, Balya, Medhya, Rasayana, Kaphavataghna, Pittahara, } \\
\text { Vatahara, Stanyakara, Hrdya, Netrya, Sukrala, Agnipushtikara }\end{array}$ \\
\hline Vidari & $\begin{array}{l}\text { Vatahara, Pittahara, Stanyada, Sukrala, Mutrala, Jivaniya, Rasayana, } \\
\text { Brimhana, Svarya, Varnya, Balya, Vrsya }\end{array}$ \\
\hline Gokshura & Vatanut, Vrsya, Brimhana, Asmarihara, Vastisodhana \\
\hline Musta & $\begin{array}{l}\text { Pittakaphahara, Sthoulyahara, Sothahara, Dipana, Pacana, Grahi, } \\
\text { Trsnanigrahana, Krimighna, Tvakdoshahara, Jwaraghna, Visaghna }\end{array}$ \\
\hline Sariva & Tridoshaghna, Dipana, Raktasodhana, Ama Nasana, Visaghna, Jwarahara \\
\hline
\end{tabular}

\section{DISCUSSION}

Lower urinary tract infections begin when the uropathogen residing in the gut contaminate the periure- thral area and can colonize at the urethra. Then they migrate to the bladder and resulting in colonization. Host inflammatory responses, including neutrophil 
infiltration, begin to clear extracellular bacteria. Either through host cell invasion or morphological changes, some bacteria evade the immune system and result in resistance to neutrophils. These bacteria undergo multiplication and biofilm formation. These bacteria produce toxins and proteases that induce host cell damage and releases essential nutrients that promote bacterial survival. If left untreated, it results in kidney colonization or even progress to bacteraemia ${ }^{1}$. In Varividaryadi Kashaya, all the drugs are having Sita Virya and most of the drugs are having Madhura Rasa, Guru- Snigdha Guna, and Madhura Vipaka. This may alleviate the vitiated Pitta in the Pittaja Mutrakrichra. The vitiated Dosha results in the reduced function of Agni; thus, the formation of Ama occurs. The Dipana and Ama Pachana properties of the Kashaya help in the Ama Pachana, Agni Dipana and thereby arrest the further formation of Ama Yukta Rasa Dhatu. In Ayurveda classics, Gokshura has been mentioned as Vatahara and Mutrakrichrahara $^{12}$. This property will alleviate the vitiated Vata Dosha in the Basti. Madhura Rasa - Vipaka and Snigdha Guna of the Kashaya increases the Kleda in the body. Kleda increases the production of urine and thereby reducing the urine $\mathrm{pH}$. The Vasti Sodhana and Mutravirechaneeya property of Gokshura helps in eliminating the excess Kleda produced, thereby the bacteria is pushed out from the bladder and reduce the inflammation.

The various activities and effects of the drugs can be explained on modern parameters as well by recent studies of their pharmacological actions. Vidarikan$d a$ contains sugar and due to their osmotic activity, these substances oppose the reabsorption of water from the glomerular filtrate. These substances produce more elimination of water than sodium and hence produce diuresis. Shatavarin 1, found in Shatavari and potassium nitrate in the Gokshura also causes diuresis ${ }^{13}$. By diuresis, there will be increased production of urine and that reduces the altered $\mathrm{pH}$ of the urine and the environment favourable for bacterial growth. From the antimicrobial studies, it was concluded that the essential oil of Cyperus rotundus rhizomes was active against gram-positive micro- organisms and they also possess anti-inflammatory activity. The extracts of $C$. rotundus show antiinflammatory activity ${ }^{14}$. The diuretic properties of Tribulus terrestris are due to the large quantities of nitrates and essential oil present in its fruits and seeds. The diuretic activity can also be attributed to the presence of potassium salts in high concentrations. Analgesic activities of Tribulus terrestris were studied and the study indicated that the methanolic extract of Tribulus terrestris at a dose of $100 \mathrm{mg} / \mathrm{kg}$ produced an analgesic effect. The methanolic extract of fruits of Tribulus terrestris is found to be most active against gram-positive and gram-negative bacteria $^{15}$. Essential oil of Hemidesmus indicus also exhibited marked antibacterial activity against both grams positive and gram-negative bacteria but failed to show appreciable antifungal activity. Chloroform and ethanol (95\%) extracts of $H$. indicus showed antifungal activity. The methanolic extracts of Hemidesmus indicus roots possess potential dosedependent anti-inflammatory and anti-pyretic activity ${ }^{16}$. Methanolic extract of Asparagus racemosus shows antibacterial activity. Aqueous extract of the roots of Asparagus racemosus shows diuretic activity. The in vitro anti-candidal activity of Asparagus racemosus roots and tubers extract showed a high degree of activity against all the Candida strains ${ }^{17}$. By considering all these pharmacological properties of different ingredients of Varividaryadi Kashaya, we can understand the counteracting effect of the Kashaya on the pathophysiology of LUTI when it is administered.

\section{CONCLUSION}

Lower urinary tract infections can be correlated with Mutrakrichra especially Pittaja Mutrakrichra. Varividaryadi Kashaya, in which all the drugs are having Sita Virya and most of the drugs are having Madhura Rasa, Guru- Snigdha Guna, Madhura Vipaka and Vata-Pitta Samana property, helps in the Samprapti Vighatana of the disease. The Vasti Sodhana and Mutravirechaneeya effect of the Gokshura plays a very important role in the elimination of bacteria through urine. 


\section{REFERENCES}

1. Flores-Mireles, A., Walker, J., Caparon, M. and Hultgren, S., 2015. Urinary tract infections: epidemiology, mechanisms of infection and treatment options. Nature Reviews Microbiology, 13(5), pp.269-284.

2. Harrison T R. Dennis L Kasper. Harrison's Principles of Internal Medicine. 20th ed. Vol. 1. Mc Graw Hill Education; 2018. Pg No.968.

3. Madhavakara, Madhavanidanam with Madhukosa commentary, translated by Dr P. Himasagara Chandra Murthy, Chowkhamba Sanskrit series office, Varanasi $3^{\text {rd }}$ ed.2013 Purvarddha, Ch.No.30, p.no.301.

4. Agnivesa. Revised by Charaka and Dridabala. Charaka Samhita with Ayurveda Dipika commentary of Chakrapanidutta, translated by Dr Ram Karan Sharma and Vaidya Bhagvan Dash; Chowkhamba Sanskrit series office, Varanasi 2013. $2^{\text {nd }}$ Vol. Vimana Sthana 5/20, p.no. 178 .

5. Agnivesa. Revised by Charaka and Dridabala. Charaka Samhita with Ayurveda Dipika commentary of Chakrapanidutta, translated by Dr Ram Karan Sharma and Vaidya Bhagvan Dash; Chowkhamba Sanskrit series office, Varanasi $20134^{\text {th }}$ Vol. Chikitsa Sthana 26/32, p.no.477.

6. Krishnan Vaidyan. K. V, GopalaPillai.S. Sahasrayogam sujanapriya commentary, $33^{\text {rd }}$ ed, vidyarambham publishers, Alappuzha. 2015. P.97.

7. The Ayurvedic pharmacopeia of India part 1. vol 1.1st ed. New Delhi; 2001.p.107.

8. The Ayurvedic pharmacopeia of India part 1. vol 4.1st ed. New Delhi; 2004.p.108-109.

9. The Ayurvedic pharmacopeia of India part 1. vol 3.1st ed. New Delhi; 2001.p.129-130.

10. The Ayurvedic pharmacopeia of India part 1. vol 2.1st ed. New Delhi; 1999.p.173-174.

11. Nighantu Adarsha by Bapalal G. Vaidya vol 1. 3rd ed.2002. Chowkhamba Bharati academy-varanasi221001. p.211.

12. Agnivesa. Revised by Charaka and Dridabala. Charaka Samhita with Ayurveda Dipika commentary of Chakrapanidutta, translated by Dr Ram Karan Sharma and Vaidya Bhagvan Dash; Chowkhamba Sanskrit series office, Varanasi 2012. $1^{\text {st }}$ Vol. Sutra Sthana 25/65, p.no.426.

13. Bhat SD, Ashok BK, Acharya R. Critical analysis of herbs acting on Mutravaha srotas. Ayu. 2010;31(2):167-9.
14. Nagarajan M, Kuruvilla GR, Kumar KS, Venkatasubramanian P. Pharmacology of Ativisha, Musta and their substitutes. $\mathrm{J}$ Ayurveda Integr Med. 2015;6(2):121-33.

15. Chhatre S, Nesari T, Somani G, Kanchan D, Sathaye S. Phytopharmacological overview of Tribulus terrestris. Pharmacogn Rev. 2014;8(15):45-51.

16. Vandana Aneja, Ashish Suthar, Sonika Verma and Satyan Kalkunte. Phoog Rev.: Plant Review Phytopharmacology of Hemidesmus indicus. PHCOG REV An official Publication of PhoogNet [Internet]. JanJun 2008;2(3):143-150. Available from: http://www.phcogrev.com

17. Arshad Hussain, Md. Parwez Ahmad, Shadma Wahab, Md. sarfaraj Hussain1 and Maksood Ali. A Review on Pharmacological and Phytochemical Profile of Asparagus racemosus Willd. Pharmacologyonline. 2011 Nov;3:1353-64.

\section{Source of Support: Nil Conflict of Interest: None Declared}

How to cite this URL: Anshu $S$ et al: Critical Evaluation of The Action Of Varividaryadi Kashaya In Lower Vrinary Tract Infections. International Ayurvedic Medical Journal \{online\} 2021 \{cited November 2021\} Available from: http://www.iamj.in/posts/images/upload/2784_2788.pdf 